\title{
Aspectos psicosociales de la adopción en Andalucía
}

\author{
José Ocón Domingo
}

Universidad de Granada

\section{Resumen}

En este artículo se recogen los cambios experimentados por el modelo tradicional de familia en España y se analizan las transformaciones sufridas por la familia adoptiva. Pero, fundamentalmente, tratamos de ofrecer una síntesis inédita de los resultados obtenidos en una amplia investigación sobre adopción en Andalucía. El planteamiento metodológico, de naturaleza cualitativa a partir de una entrevista abierta a los cónyuges de un grupo de siete familias adoptivas, la profundización en los significados que los protagonistas atribuyen a cada uno de los elementos que configuran un proceso adoptivo y sobre algunos temas no considerados en estudios previos, como es el caso de los fundamentos de las paternidades adoptiva y biológica, constituyen un grupo de novedades a destacar en este trabajo.

Palabras clave: familia tradicional, familia adoptiva, investigación, paternidad biológica, paternidad adoptiva.

\section{Abstract. Psycho-social aspects of adoption in Andalucia}

In this article we have described the changes in the traditional family model in Spain and the transformations of the adoptive family. In addition to this, our main objective is to produce an unprecedented synthesis of a wide researching project about adoption in Andalucía. Our methodology has a qualitative focus and is based on an open interview to the spouses of seven adoptive families. The innovations of our project include a deep study of the fundamentals of the adoptive and biologic paternity and the meanings of the elements that configure the adoptive process for any of the interviewed spouses.

Key words: traditional family, adoptive family, researching, biologic paternity, adoptive paternity. 


\section{Sumario}

Introducción Información de la condición de adoptado

Devenir de la familia adoptiva

Planteamiento de la investigación

Negativa de la naturaleza

Motivación para adoptar

Iniciativa y comunicación de la adopción Paternidad adoptiva y paternidad biológica

Necesidad de los niños de contar con una familia

Características solicitadas en los niños Selección, tiempo de espera y seguimiento Información de la familia adoptiva
Reacciones de los adoptados

Información sobre los antecedentes y orígenes

Interés por los orígenes:

posiciones paternales

Adaptación familiar y escolar

Satisfacción con la adopción

Las actitudes en torno a la adopción

Conclusiones

Referencias bibliográficas

\section{Introducción}

El hecho de que, en las sociedades desarrolladas, el papel de la familia se haya debilitado con motivo de la creciente participación de otras instituciones del Estado, no ha impedido que siga constituyendo el referente imprescindible, más intenso y persistente de la vida emocional de los individuos (Ocón, 2005a). Pero esta persistencia no ha impedido que las modificaciones en los valores, las creencias, las actitudes y las costumbres sociales operadas en España con el devenir democrático también se hayan reflejado en la familia (Ocón, 2005b). Así lo indica Alberdi (1995: 382): «Por tanto, la familia en los albores del siglo XXI, ya no es la de antaño ni las normas jurídicas pueden ser las mismas. Una sociedad plural basada en relaciones de igualdad y libertad dan lugar a muy diversas formas de relaciones familiares todas ellas válidas y aceptadas por el derecho». Estas nuevas circunstancias, sin embargo, no han socavado su valoración social: un 95,7 \% de los ciudadanos de la Unión Europea (15) opina que la familia constituye el hecho más importante de sus vidas, por delante del trabajo $(90,2 \%)$, de los amigos y conocidos (88,3\%) y del ocio (84,3\%) (Meil, 1999: 16).

Ahora bien, con cierta independencia de estas nuevas formas familiares, entre las que destaca la familia homoparental, las connotaciones que actualmente reviste la familia adoptiva, como recogemos más adelante, constituyen una muestra adicional de la envergadura alcanzada por estas transformaciones familiares en España, además de un vivo ejemplo del afán de una gran mayoría de seres humanos por contar con un núcleo familiar permanente y estable.

\section{Devenir de la familia adoptiva}

Uno de los principales cambios observados en estas familias, desde el punto de vista de la protección, consiste en el traslado de intereses del terreno de los 
adultos al de los niños. Ahora no se trata de encontrar una vía para dar continuidad a las herencias, a los apellidos o al culto doméstico. Tampoco de rellenar los huecos dejados por un hijo que se ha perdido, de hacer una buena obra de caridad o de cubrir la vergüenza social derivada de una esterilidad (Assiego, 1998; Morral, 1987, Rodrígues, 1997). Actualmente, es el niño el único que tiene derecho a la adopción, y no cualquier niño, sino uno particular y adecuado; y su protección es una responsabilidad del Sistema Público de Servicios Sociales ${ }^{1}$ (Castón y Ocón, 2002).

La paternidad adoptiva se ha extendido a todos los niveles educativos y categorías profesionales. Ya no puede entenderse como una realidad exclusiva de familias con problemas de descendencia y avaladas por un determinado nivel socioeconómico. Y es que la adopción ha venido democratizándose con la sociedad española, alcanzando su máxima expresión con la novedad que supone la posibilidad legal de matrimonio y adopción brindada recientemente a los homosexuales en España ${ }^{2}$. Las estadísticas disponibles sobre este recurso en España constituyen la mejor prueba de la expansión que venimos subrayando, sobre todo por el auge alcanzado por la adopción internacional, que ha crecido un $488 \%$ entre los años 1997 y 2004. Concretamente, los valores globales son los siguientes: 942 (1997), 1.487 (1998), 2.006 (1999), 3.062 (2000), 3.428 (2001), 3.625 (2002), 3.951 (2003), 5.541 (2004). La mayoría de los niños y niñas, en el año 2004, provienen del continente asiático (2.577) (gráfico 1). Sin embargo, las adopciones nacionales se mantienen constantes en torno al millar: 1.025 (1996), 849 (1997), 875 (1998), 868 (1999), 964 (2000), 1.075 (2001), 1.028 (2002), 896 (2003) (gráfico 2).

Asimismo, podemos apreciar la eficacia de esta medida observando la integración familiar y escolar de los adoptados recogida en las escasas investigaciones españolas ${ }^{3}$, que se han desarrollado bajo un enfoque predominantemente positivista (Ocón, 2002).

1. Estos nuevos cometidos surgen en virtud de la aprobación de la Constitución española, quedando plasmados en las leyes protectoras 21/1987 (BOE. núm. 275, de 17 de enero) y 1/1996 (BOE., núm. 15, de 17 de enero) en concordancia con lo estipulado en la legislación internacional, básicamente en la Convención de los Derechos del Niño de 1989 (ratificada por España el 31 de diciembre de 1990) y en el Convenio de La Haya de Derecho Internacional Privado de 1993 (ratificado por España el 11 de junio de 1995).

2. De modo que España, tras Holanda (2000), Bélgica (2003) y Canadá (2005), se ha convertido en el cuarto país del mundo en regular nacionalmente la institución matrimonial homosexual, por Ley 13/2005 (BOE de 1 de julio de 2005).

3. No obstante, algunas adopciones no resultan tan exitosas, como se destaca en un trabajo reciente a cargo de A. BERÁsTEGUI PEDRO-VIEJO (2003), Las adopciones internacionales truncadas y en riesgo en la Comunidad de Madrid, Consejo Económico y Social, CAM. Las otras corresponden a P. AMORÓs (1987), La adopción y el acogimiento familiar, Barcelona, Narcea; Martí X. MARCH (1993), La adopción en Mallorca. Una investigación evaluativa, Palma de Mallorca, Universidad de las Islas Baleares, Consejería de Gobernación y Dirección General de la Juventud, Menor y Familia, y J. PALACiOS y otros (1997), La adopción en Andalucía, Sevilla, Consejería de Asuntos Sociales (Junta de Andalucía). 


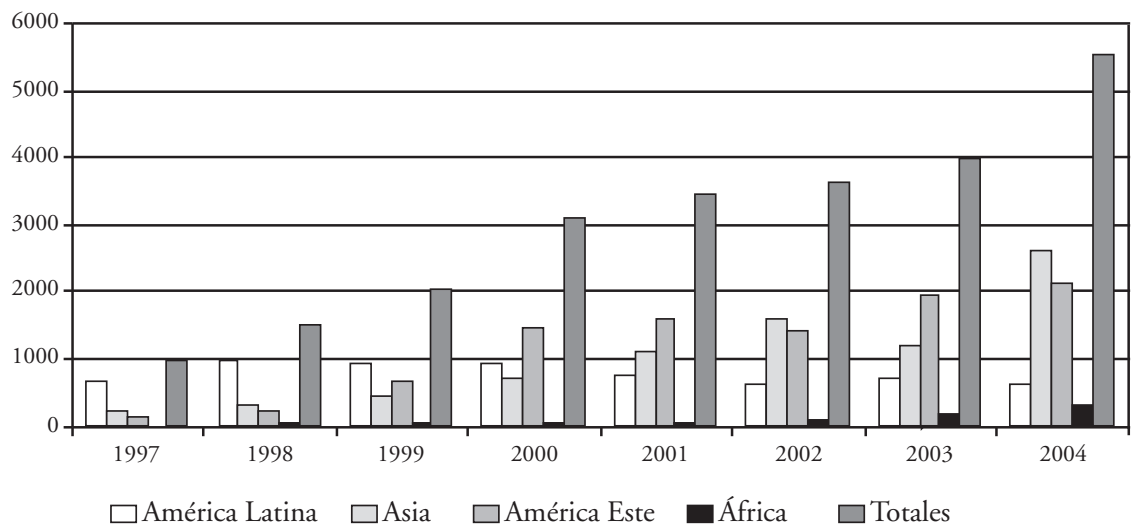

Gráfico 1. Adopciones internacionales por continentes (1997-2004). Fuente: Consulados españoles en el extranjero. Citado por la Secretaría de Estado de Servicios Sociales, Familias y Discapacidad (Ministerio de Trabajo y Asuntos Sociales, 2006: 89). Elaboración propia.

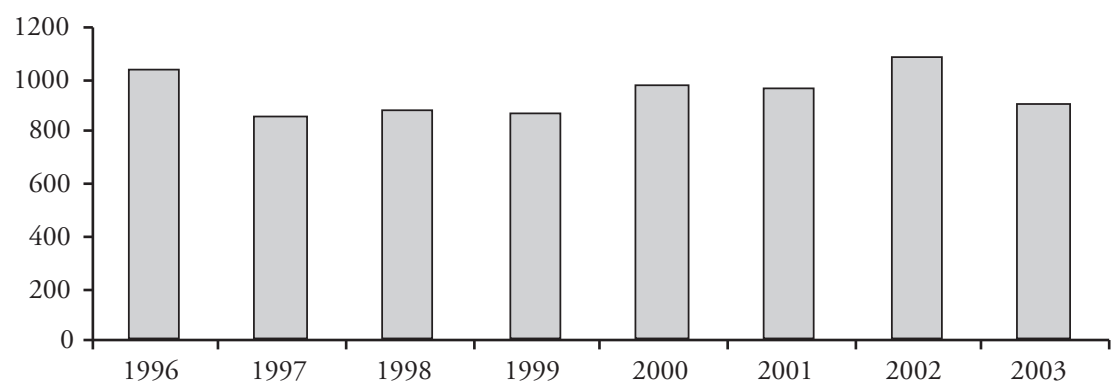

Gráfico 2. Adopciones nacionales (1996-2003). Fuente: Comunidades autónomas. Citado por la Secretaría de Estado de Servicios Sociales, Familias y Discapacidad (Ministerio de Trabajo y Asuntos Sociales, 2006: 20). Elaboración propia.

Por otra parte, es conocido que muchos adoptados han finalizado sus vidas convencidos de crecer en una familia biológica, y no pocos quienes han descubierto estas circunstancias de adultos. Este secretismo, que afectaba a los propios hijos, familiares, amigos y vecinos, ha quedado muy desfasado. El conocimiento de este estatus y de los antecedentes (que se conoce por «revelación») se erige en pilar básico de todo proceso adoptivo. De modo que los especialistas, valorando su influencia en el desarrollo de la identidad, muestran acuerdo en comunicar esta información al niño por razones de orden 
moral, psicológico y material ${ }^{4}$ (Amorós, 1987; Giberti, 1981; Fuertes y Amorós, 1996; Orellana, 1993; Hernán Quiroz, 1996; Ruskai, 2001). Éstas y otras connotaciones han permitido que, en poco tiempo, la adopción sea un asunto mucho más abierto y de notable relevancia social.

En definitiva, este protagonismo y la necesidad de incrementar la producción científica sobre adopción en España hicieron que nos inclináramos por conocer la propia experiencia adoptiva de un grupo de familias andaluzas. De modo que ahora tratamos de ofrecer una síntesis inédita de los aspectos metodológicos, contenidos y resultados más relevantes de esta investigación 5 .

\section{Planteamiento de la investigación}

Con este trabajo, fruto de mi interés en el campo de la familia y la infancia, he tratado de cubrir el siguiente objetivo general: conocer la realidad psicológica y social que ha caracterizado los procesos adoptivos de un grupo de familias andaluzas. De estas familias, tres habían formalizado una adopción nacional, otras tres internacional, y una se encontraba en fase de acogimiento preadoptivo $^{6}$. El procedimiento para la selección de las familias ha sido el denominado «bola de nieve», cuyos perfiles me han posibilitado un análisis de naturaleza psicosocial (cuadro 1). Todos los procesos adoptivos se desarrollaron bajo el marco legislativo actual, representado por la Ley Orgánica 1/1996, de 15 de enero, de Protección Jurídica del Menor. Para conocer estas experiencias familiares, se ha optado por una metodología cualitativa, basada en una entrevista abierta en profundidad a estos padres y madres adoptivos. Tales procedimientos resultan muy apropiados cuando se trata de indagar en asuntos relacionados con la vida privada y tan cargados de afectividad y emotividad como, en nuestro caso, es la adopción. Y es que, como indica Valles (1997), la entrevista en profundidad es pertinente en asuntos difíciles, permitiendo extraer una gran riqueza informativa, de carácter contextualizado u holístico y personalizado, y el contraste de los resultados obtenidos con procedimientos cuantitativos. Asimismo, hemos considerado que la unidad de registro más adecuada para analizar las circunstancias que confluyen en la adopción y rea-

4. Este derecho, entre otras normativas, está recogido en la Declaración de las Naciones Unidas sobre los Principios Sociales y Jurídicos relacionados con la Protección y Bienestar de los Niños, con especial referencia a la Adopción y a la Colocación en Hogares de Guarda, en los planos Nacional e Internacional, de 1986 (art. 9). También en el Convenio de La Haya de Derecho Internacional Privado de 1993, en materia de adopción internacional (arts. 16, 30 y 31$)$.

5. José Ocón Domingo (2003), Aspectos psicosociales de la adopción en Andalucía (Una aproximación socio-histórica y jurídico-administrativa), Granada, Departamento de Sociología, Facultad de Ciencias Políticas y Sociología, Universidad de Granada (tesis doctoral no publicada).

6. La inclusión de esta familia ha sido intencional. Se trataba de contrastar su experiencia con las restantes familias que sí habían formalizado la adopción. 
Cuadro 1. Perfiles familiares de padres y adoptados.

\begin{tabular}{|c|c|c|c|c|c|c|c|}
\hline $\begin{array}{l}\text { Identificación } \\
\text { de padres adoptivos }\end{array}$ & $\begin{array}{l}\text { Estudios } \\
\text { de los padres }\end{array}$ & $\begin{array}{l}\text { Situación } \\
\text { profesional } \\
\text { de los padres }\end{array}$ & $\begin{array}{l}\text { Hábitat } \\
\text { de la familia }\end{array}$ & $\begin{array}{l}\text { Estudios } \\
\text { de los hijos }\end{array}$ & $\begin{array}{l}\text { Edad de acogida } \\
\text { de los hijos }\end{array}$ & $\begin{array}{l}\text { Edad en entrev. } \\
\text { de los hijos }\end{array}$ & $\begin{array}{l}\text { Modalidad } \\
\text { de adopción }\end{array}$ \\
\hline $\begin{array}{l}\text { Pablo y Carmela } \\
\text { (F1) }\end{array}$ & $\begin{array}{l}\text { Pablo: CEP } \\
\text { Carmela: CEP }\end{array}$ & $\begin{array}{l}\text { Pablo: camarero } \\
\text { Carmela: sus labores }\end{array}$ & Rural & $\begin{array}{l}\text { Marta: } 2^{\circ} \mathrm{ESO} \\
\text { Ignacio: preescolar }\end{array}$ & $\begin{array}{l}\text { Marta: } 7 \text { años } \\
\text { Ignacio: } 6 \text { meses }\end{array}$ & $\begin{array}{l}\text { Marta: } 15 \text { años } \\
\text { Ignacio: } 5 \text { años }\end{array}$ & $\begin{array}{l}\text { Marta: nacional } \\
\text { Ignacio: nacional }\end{array}$ \\
\hline $\begin{array}{l}\text { Jacinto y Elvira } \\
\text { (F2) }\end{array}$ & $\begin{array}{l}\text { Jacinto: CE } \\
\text { Elvira: GE }\end{array}$ & $\begin{array}{l}\text { Jacinto: guarda } \\
\text { Elvira: confección }\end{array}$ & Rural & Ignacio: guardería & Ignacio: 8 meses & Ignacio: 3 años & Ignacio: nacional \\
\hline $\begin{array}{l}\text { Pedro y Angustias } \\
\text { (F3) }\end{array}$ & $\begin{array}{l}\text { Pedro: EU } \\
\text { Angustias: EU }\end{array}$ & $\begin{array}{l}\text { Pedro: médico } \\
\text { Angustias: becaria } \\
\text { inv. }\end{array}$ & Urbano & $\begin{array}{l}\text { Olga: } 6^{\circ} \mathrm{EP} \\
\text { Leticia: } 5^{\circ} \mathrm{EP} \\
\text { Óscar: } 2^{\circ} \mathrm{EP}\end{array}$ & $\begin{array}{l}\text { Olga: } 4 \text { años } \\
\text { Leticia: } 3 \text { años } \\
\text { Óscar: } 2 \text { meses }\end{array}$ & $\begin{array}{l}\text { Olga: } 12 \text { años } \\
\text { Leticia: } 11 \text { años } \\
\text { Óscar: } 8 \text { años }\end{array}$ & $\begin{array}{l}\text { Olga: nacional } \\
\text { Leticia: nacional } \\
\text { Óscar: nacional }\end{array}$ \\
\hline $\begin{array}{l}\text { Juan y Ana } \\
\text { (F4) }\end{array}$ & $\begin{array}{l}\text { Juan: EU } \\
\text { Ana: EU }\end{array}$ & $\begin{array}{l}\text { Juan: profesor } \\
\text { Ana: pensionista }\end{array}$ & Rural & $\begin{array}{l}\text { Rebeca: } 4^{\circ} \mathrm{EP} \\
\text { Marisa: } 2^{\circ} \mathrm{EP}\end{array}$ & $\begin{array}{l}\text { Rebeca: } 5 \text { años } \\
\text { Marisa: } 3 \text { años }\end{array}$ & $\begin{array}{l}\text { Rebeca: } 9 \text { años } \\
\text { Marisa: } 7 \text { años }\end{array}$ & $\begin{array}{l}\text { Rebeca: nacional } \\
\text { Marisa: nacional }\end{array}$ \\
\hline $\begin{array}{l}\text { Santiago y María } \\
\text { (F5) }\end{array}$ & $\begin{array}{l}\text { Santiago: CEP } \\
\text { María: EU }\end{array}$ & $\begin{array}{l}\text { Santiago: } \\
\text { comerciante } \\
\text { María: trabajadora } \\
\text { social }\end{array}$ & Rural & Mariano: guardería & $\begin{array}{l}\text { Mariano: tras } \\
\text { alumbramiento }\end{array}$ & Mariano: 2 años & $\begin{array}{l}\text { Mariano: } \\
\text { internacional }\end{array}$ \\
\hline $\begin{array}{l}\text { Nicolás y Patricia } \\
\text { (F6) }\end{array}$ & $\begin{array}{l}\text { Nicolás: EU } \\
\text { Patricia: EU }\end{array}$ & $\begin{array}{l}\text { Nicolás: profesor } \\
\text { Patricia: enfermera }\end{array}$ & Urbano & $\begin{array}{l}\text { Eva: } 4^{\circ} \mathrm{EP} \\
\text { Yolanda: } 3^{\circ} \mathrm{EP}\end{array}$ & $\begin{array}{l}\text { Eva: } 10 \text { años } \\
\text { Yolanda: } 3 \text { años }\end{array}$ & $\begin{array}{l}\text { Eva: } 16 \text { años } \\
\text { Yolanda: } 8 \text { años }\end{array}$ & $\begin{array}{l}\text { Eva: internacional } \\
\text { Yolanda: } \\
\text { internacional }\end{array}$ \\
\hline $\begin{array}{l}\text { José y Adela } \\
\text { (F7) }\end{array}$ & $\begin{array}{l}\text { José: EU } \\
\text { Adela: EU }\end{array}$ & $\begin{array}{l}\text { José: profesor } \\
\text { Adela: profesora }\end{array}$ & Urbano & $\begin{array}{l}\text { Lorena: } 5^{\circ} \mathrm{EP} \\
\text { Luis: preescolar }\end{array}$ & $\begin{array}{l}\text { Lorena: } 8 \text { años } \\
\text { Luis: } 3 \text { años }\end{array}$ & $\begin{array}{l}\text { Lorena: } 10 \text { años } \\
\text { Luis: } 5 \text { años }\end{array}$ & $\begin{array}{l}\text { Lorena: } \\
\text { internacional } \\
\text { Luis: internacional }\end{array}$ \\
\hline
\end{tabular}


lizar una exploración flexible, adaptable y próxima a la realidad es el tema. Básicamente porque la realidad adoptiva, antes que a un orden lingüístico, se acomoda a un orden psicosociológico.

Esta investigación, además de los aspectos metodológicos, tiene de relevancia el estudio de las adopciones internacionales y la profundización en ciertas dimensiones que no han sido tratadas en estudios precedentes. Nos referimos, básicamente, a las siguientes: sentimientos despertados por la infertilidad, comparación entre las paternidades biológica y adoptiva, necesidad de los niños de contar con una familia, posiciones paternales en torno a la «revelación» de los antecedentes y orígenes, actitudes sobre adopción internacional, abierta, homosexual y con relación al mismo concepto de adopción. De modo que, orientados por el objetivo general mencionado, en una larga y exhaustiva entrevista en profundidad, tratamos de cubrir otros de carácter más específico relacionados con todo un conjunto de temas y aspectos de relevancia en los procesos adoptivos. Con esta finalidad, se procedió a una recogida y a un análisis de información de lo siguiente:

1. La constitución de la familia adoptiva: negativa de la naturaleza; motivación para adoptar; iniciativa y comunicación de la adopción; paternidad adoptiva y paternidad biológica; necesidad de los niños de contar con una familia.

2. Las relaciones con los servicios de adopción: características solicitadas en los niños; selección, tiempo de espera y seguimiento adoptivo.

3. El proceso de "revelación»: información de la familia adoptiva; información de la condición de adoptado; reacciones de los adoptados; información sobre los antecedentes y orígenes; interés por los orígenes: posiciones paternales.

4. La integración familiar y escolar del adoptado.

5. La satisfacción con la adopción.

6. Las actitudes en torno a la adopción internacional, homosexual, abierta y al concepto de adopción.

Estas características de padres e hijos, junto a la naturaleza de cada adopción, nos han posibilitado diferenciar los significados otorgados por los cónyuges a sus respectivas experiencias, según la influencia que, en los distintos aspectos considerados, les haya sido atribuida. Para asociar los fragmentos de los discursos a cada configuración familiar y otorgar un mayor realismo al texto, hemos seguido un sistema de notación específico que, como vemos, consiste en asignar un nombre ficticio a los padres y madres, así como a los hijos, acompañado de la letra «f» (inicial de familia) y de un número que designa el orden establecido (f1, f2, f3, etc.). La referencia a las preguntas realizadas por el autor se hace con la fórmula «Entrevistador». Asimismo, la transcripción de los mensajes (que habían sido registrados previamente en una grabadora), agrupados según las distintas temáticas, nos posibilitaron su análisis y el conjunto de significados que tratamos de recoger a continuación. Sin embargo, por motivos de espacio, sólo tratamos de ofrecer un resumen de los resultados obtenidos. 


\section{Negativa de la naturaleza}

Todos los matrimonios, salvo uno $(f 7)^{7}$, acudieron a la adopción por la imposibilidad de tener hijos. La gran mayoría, a excepción de (f5), vivieron este proceso de modo obsesivo, acompañado de episodios de angustia, sensación de fracaso y otros trastornos psicológicos. Estas circunstancias, contrarias a los deseos personales de los cónyuges y a las expectativas del entorno, hicieron que todas las esposas, con la excepción de Adela (f7), se sometieran a tratamientos médicos para encontrar una solución. A modo de ejemplo:

Elvira: Fue él [su marido] quien decidió que no me pusieran más tratamientos, porque yo estaba ya ciega, porque en una ocasión estuve a punto de que me pasara cualquier cosa. Mis pulmones ya no aguantaban porque se encharcaron con quince quilos de retención, y eso es monstruoso. No me podía mover. Es que intentamos la inseminación artificial hasta seis veces (f2).

Este empeño por acomodarse al modelo de familia biológica ha sido más evidente en las mujeres, quienes también vivieron la infertilidad de un modo más negativo. Se percibe, asimismo, cómo esta problemática ha resultado una carga añadida para el miembro estéril de la pareja. Algunos mensajes, igualmente, alertan de cómo el binomio formado por fertilidad e infertilidad prestigia o denigra a la pareja según pueda demostrarse la capacidad de tener hijos biológicos. La infertilidad es un problema atribuido por el entorno inicialmente a la mujer. Esta situación ha hecho a algunos matrimonios semantizar el secretismo que ha acompañado a los tratamientos médicos, que puede constituir un reflejo de la concepción social imperante, sobre todo en medios rurales, de que la maternidad es el rol más preciado de la mujer. Por el lado del varón, parece que la ausencia de hijos tampoco ha conseguido desligarse totalmente de la impotencia sexual. El hecho de que los matrimonios con un nivel cultural y profesional más bajo, y de hábitat rural, sean los que se muestren más celosos con la trascendencia de esta incapacidad, puede fundamentar nuestras apreciaciones:

CARMELA: Porque no te gusta que se entere la gente, porque la gente va a ir diciendo: que si no pueden tener hijos, que si esto, que si lo otro... (f1).

JACINTO: Era mayormente por las habladurías de la gente, que siempre empieza: que si porqué no podrán tener hijos, que si tal y que si cual... (f2).

\section{Motivación para adoptar}

La mayoría de las familias iniciaron el camino de la adopción impulsadas por el deseo de constituir y disfrutar de una familia. Otras, sin embargo, aducen ciertas motivaciones relacionadas con proporcionar una compañía o un dinamis-

7. Cuyos hijos habían fallecido a consecuencia de una grave enfermedad genética. 
mo a la pareja y/o con la ayuda a los niños necesitados (f2, f4 y f5). Como vemos, los perfiles familiares son dispares y no se puede establecer una relación entre los mismos y la naturaleza de las motivaciones. Veamos qué dicen algunos padres de ambos perfiles:

JACINTO: Una casa sin niños es como un jardín sin flores. El matrimonio cuando tiene hijos se une mucho más, y el zagal ya te da otra alegría a la familia, otra compañía, otra forma de ver la vida, de... Es otra cosa, es otra cosa (f2).

José: Hay padres que queremos ser padres, no ser acogida ni hacer nada por altruismo, ser padres que es lo que quiere ser todo hombre, toda persona que adopta (f7).

Sin embargo, se observa que algunas esposas, impulsadas prioritariamente por formar una familia, también añaden razones relacionadas con la ayuda a los niños, así como a la inversa. En general, quizás como resultado de un proceso de socialización diferenciado, son las mujeres las más inclinadas al altruismo.

\section{Iniciativa y comunicación de la adopción}

La iniciativa para proceder a la adopción, a excepción de dos parejas de elevado estatus y urbanas que lo deciden conjuntamente ( $\mathrm{f} 5 \mathrm{y} \mathrm{f7}$ ), surge siempre de la mujer. Si bien estas propuestas reciben una buena acogida por sus esposos, los menos receptivos siguen siendo los de aquellas estructuras familiares con características socioculturales más bajas y de residencia rural:

ELVIRA: Él, a lo primero decía que no, pues nosotros los íbamos a tener, y yo me quedé con la respuesta de mi marido muy fría (f2).

Por otra parte, la mayoría de parejas comunica esta iniciativa a los familiares y amigos más cercanos, argumentando las que no lo hacen razones de privacidad e intimidad familiar ( $\mathrm{f} 2 \mathrm{y} \mathrm{f} 3$ ). Estas familias, como vemos, presentan perfiles muy dispares, siendo las de residencia rural y estatus bajo las más preocupadas por la trascendencia de estos asuntos:

PABLO: Pues... Es que es una cosa particular y la gente no tiene por qué enterarse. A la familia nuestra porque, si tú tienes un hijo, lo que pasa es que se lo dices, pero la gente enseguida empieza: que si van a adoptar, que si qué niño le darán, que si esto, que si lo otro... (f1).

$\mathrm{Si}$, como decimos, las reacciones de familiares y amigos han sido positivas, cuando se produce el conocimiento de la etnia gitana de dos acogidas, estas respuestas se perciben muy condicionadas y sin muestra alguna de agrado.

ANA: La raza, la raza. La raza no la han aceptado bien. Ya la están aceptando por nosotros, claro, por ellas... (f4). 


\section{Paternidad adoptiva y paternidad biológica}

Otro tema importante es la concepción que los padres tienen de la paternidad adoptiva en comparación con la biológica, así como la importancia que, en la formación de la personalidad y conducta de los niños, atribuyen a la genética y al aprendizaje. Hemos de tener en cuenta, entre otras consideraciones, que algunos matrimonios han experimentado ambas paternidades, y esta circunstancia les coloca en una posición privilegiada. En definitiva, todos establecen una notable similitud entre ambos procesos, pues dicen que los adoptados son hijos tan deseados y queridos como los biológicos, y no destacan diferencias en el tema de las responsabilidades paternales. Esta equiparación se produce incluso antes de la acogida de los niños, para continuar de manera inevitable. El esposo de nuestro estudio, que aún se encuentra en fase preadoptiva, confiesa lo siguiente:

JUAN: Es decir, tú a la cabra le puedes quitar el cabritillo, pero hasta que lo lama, cuando lo lama ya no se lo quitas, porque te muerde. Antes de que los conozcas, los ves desde otro punto de vista, pero desde el momento en que los lames, ya cambia todo ¿sabes? (f4).

Como ocurre en los aspirantes a una paternidad biológica, varios adoptivos hacen referencia a los deseos, ilusiones y fantasías en torno a las características de sus futuros hijos. María, dirigiéndose a su marido, le recuerda: «Tú sabes que, antes de que naciera el niño, decíamos... ¿Cómo será? ¿Cómo no será? Yo me imaginaba la cara, las piernas gordillas y negrillas» (f5). Bastantes establecen una evidente comparación entre el tiempo de espera adoptivo y el embarazo biológico, así como entre la acogida del niño y el parto. Y otras se detienen en la igualdad a la hora de desempeñar las responsabilidades paternales. Un padre, que tiene un hijo biológico y otros adoptados, sostiene:

PEDro: Los sentimientos, trato, etc., respecto a un hijo biológico y uno adoptado es exactamente igual, no hay diferencia alguna. Eso de que eres de donde paces y no de donde naces es bastante aplicable (f3).

Esta equivalencia de paternidades encuentra su mejor explicación en la influencia que, en lo relacionado con el desarrollo de la personalidad y la conducta, todas las familias otorgan al ambiente y a la educación en detrimento de la naturaleza. Veamos uno de estos comentarios:

NiCOLÁs: El concepto de padres no es un concepto biológico. Es decir, padre es una hipoteca que perdura siempre, por lo que estás dispuesto a perdonar, a corregir, a sentir, a compartir... (f6).

Únicamente dos esposas, de perfil más bajo y rurales (f1 y f2), hablan de cierto peso de la genética. Una de ellas atribuye un «carácter especial» a la ascendencia gitana de su hijo Ignacio: 
ELVIRA: Un niño es lo que se hace y no cómo nace, aunque luego los genes están ahí. La madre de mi hijo es de raza gitana y el padre es desconocido, pero eso no nos importó. Pero, solamente la inclinación de ser de raza gitana puede animarlo a buscar tanto sus raíces, que me da... (f2).

No obstante, en este terreno de las matizaciones, algunos matrimonios pretenden, si cabe, una mayor consideración de la paternidad adoptiva que de la biológica, básicamente porque la primera no puede resultar de embarazos casuales y siempre constituye la expresión de un deseo consciente. Además, con motivo de la evaluación técnica "soportada», algunos subrayan una mayor preparación de los adoptivos para desempeñar las distintas funciones paternales:

NiCOLÁS: Si yo parto del hecho prioritario de que, cualquier persona que se haya previamente motivado y que va a ser evaluado, nada más que por dar ese paso, doy yo por hecho que está en condiciones de ser padre, más, en principio, que cualquier otro que lo haya tenido por un cauce biológico, sin plantearse siquiera que... Que lo que estaban era preparándose para ser padres, simple y llanamente porque haya surgido un embarazo. Mientras que el niño adoptado siempre va a ser un niño esperado ( $f(6)$.

Otra madre, a raíz de los comentarios de algunas personas del entorno rural en que reside, se encuentra obligada a atribuir mayor intensidad a los sufrimientos de este tiempo de espera adoptivo que a los derivados de un embarazo, bajo la justificación de que este periodo siempre es inferior al necesario para la acogida. Así responde Elvira: «Pues a éste también lo he parido yo, porque me ha costado cinco años de embarazo» (f2). Continuando con esta defensa, un esposo, quizás sin pretenderlo, hace alusión a la posibilidad que tienen los padres adoptivos, frente a los biológicos, de experimentar simultáneamente un conjunto de vivencias comunes:

SANTIAGO: Porque luego dicen que un embarazo, que parir y eso, y yo les digo: mira, si tú has pasado nueve meses, tú hazte una idea de lo que hemos pasado nosotros, que llevamos tres años detrás del niño (f5).

\section{Necesidad de los niños de contar con una familia}

Todas las familias han tenido la ocasión de comprobar los fuertes deseos que tienen los niños institucionalizados de encontrar una familia que los proteja y ayude a satisfacer sus distintas necesidades. Tales circunstancias hacen que estos niños perciban la adopción como una especie «lotería» con que son agraciados los compañeros que consiguen una familia. De modo que la salida de un niño supone todo un acontecimiento y, para aquéllos que siguen en los centros, una gran decepción. Los comentarios de los niños, reproducidos por padres y madres, informan del desasosiego ante la llegada de los adoptantes, de la alegría reportada por tan esperado encuentro, de la unión nacida de los 
primeros contactos, e incluso de las rivalidades por contar de inmediato con un hogar familiar permanente y estable:

CARMELA: Me dio pena, porque un niño se acercó a mí y dijo: «iQué suerte va a tener!». Había muchos niños cuando salíamos, aquello parecía una película de las de antes, nosotros con el niño y todos los demás detrás (f1).

\section{Características solicitadas en los niños}

Las familias, sin excepción, se interesan por la adopción de niños sanos, pues, como todos los padres, desean disfrutar de hijos con buena salud y dicen no sentirse preparados para afrontar problemáticas especiales:

MARÍA: Bueno, es que nosotros pusimos en la solicitud que queríamos un niño sano. ¿Por qué? Bueno, te contesto a ti: porque si yo estuviera embarazada intentaría que el niño saliera sano, que si después se pone malo, pues mala suerte, es mío (f5).

Otros argumentos tienen que ver con la escasez de tiempo y de recursos económicos para atenderlos, con la ausencia de preparación psicológica para aceptarlos y con el rechazo a repetir experiencias con niños enfermos. En cuanto al sexo, se recoge una completa uniformidad: padres y madres muestran su indiferencia con esta variable. Sin embargo, en torno a la edad, la mayoría desea niños y niñas entre tres y seis años, reconociendo su importancia las parejas que no incluyen este requisito en sus demandas. Las razones se centran en su influencia en el desarrollo de la personalidad y en la conducta e integración familiar de los niños:

Pedro: Para que de una adopción realmente podamos hablar en términos positivos, tiene que haber habido una integración, y para que haya una integración, dejémonos de fantasmas, es una realidad, cuanto menor sea el niño, más facilidades hay por parte de los padres para aceptar a ese niño como hijo $y$, por parte del niño, para aceptar a esos padres (f3).

Se constata, asimismo, cómo la etnia gitana de los niños es un inconveniente para las familias que comparten un hábitat rural, porque rechazaron su acogimiento, reflexionaron sobre su conveniencia o, en caso de acogida, me comentaron algunos problemas. No obstante, los matrimonios advierten que estas reticencias tienen que ver con la marginación detectada en estos entornos y no con prejuicios personales. Estas actitudes, por otra parte, pueden ilustrar sobre el tradicional rechazo que la sociedad española viene mostrando hacia el colectivo de los gitanos. Una madre dice:

Carmela: Mi marido dijo que gitanillos no quería. Por eso es por lo que te he dicho que la psicóloga le dijo que el que estaba para psicólogo era él. ¡Fíjate que la niña tenía pinta de gitanilla, cuando la vimos el primer día! (Risas.) Pues 
me dijo: «№!, que en un pueblo se margina a los niños así, todavía, y no quiero que mi niña pase ningún mal trago, ni pase...». Es su manía (f1).

\section{Selección, tiempo de espera y seguimiento}

En el tema de selección de las parejas, los discursos informan de diversos aspectos. Respecto al número de entrevistas, se observa cierta disparidad, pues las parejas de adopción nacional fueron entrevistadas entre una y tres ocasiones $\mathrm{y}$, las de internacional, refieren dos: una para la nacional y otra para la internacional. Por otra parte, a fin de garantizar el desarrollo y el bienestar de los niños, salvo un esposo (f6), los restantes cónyuges muestran su conformidad con este requisito:

ANA: Perfectamente, para eso los técnicos tienen unos estudios y pueden detectar si las personas están equilibradas o no lo están. Tienen que ver... Es que puede haber algún desequilibrado que vaya a por los niños y... (f4).

Este consenso no impide, sin embargo, que más de la mitad de las familias se muestre disconforme con el instrumento de la entrevista. En su conjunto, las críticas se dirigen hacia varios aspectos: muy extensas, contenidos inadecuados; insuficiente motivación, preparación, experiencia, asertividad y otras habilidades sociales de los profesionales; necesidad de que los técnicos tengan, como requisito imprescindible, la experiencia de padres, e intromisión en la intimidad de la pareja. El siguiente fragmento acapara parte de estas críticas:

NICOLÁs: Hombre, por favor, ahí no puedes tú poner a una persona inmadura, que no tenga ni idea, ni experiencia, pues porque simplemente haya estudiado Psicología. Pero ¿qué es Psicología? Pon ahí a una persona que sienta especial motivación con lo que está haciendo, que sepa cuáles son sus funciones, que sepa cómo se pasa una entrevista, que sepa cuál es su función, y punto (f3).

Los matrimonios menos tolerantes con la entrevista y con su práctica profesional son los de perfil sociocultural más alto y de ámbito urbano (f3, f4, f5, $\mathrm{f} 6$ y f7). Cuando se constata alguna disparidad de criterios, son ellas quienes se muestran más complacientes. Las parejas más críticas e insatisfechas con la Administración son las que, habiendo solicitado simultáneamente ambas modalidades, terminaron formalizando una adopción internacional ( $\mathrm{f} 6 \mathrm{y} \mathrm{f7)}$ ).

Los tiempos de espera entre la solicitud y la incorporación de los niños también resultan variables, así como calificados y vividos por los cónyuges de adopción nacional de modo dispar. Algunas parejas, que comparten un ámbito rural (f1, f2 y f4), describen estas vivencias acompañadas de inseguridad, intranquilidad y nerviosismo:

CARMEla: Con mucho nerviosismo, no fueran a no darnos un niño, pues yo llamaba cada instante a ver lo que pasaba. Ya me conocían en Menores de llamar tanto (f1). 
Si bien el periodo de acogimiento familiar preadoptivo otorga cierta seguridad sobre la permanencia definitiva del niño o la niña, son las esposas las menos convencidas: tienen miedo a una intromisión de la familia biológica que interfiera el proceso adoptivo. La formalización de la adopción, curiosamente, apenas modifica la inquietud de estas madres. La familia de mi estudio aún en acogimiento preadoptivo exterioriza un alto grado de ansiedad y pesimismo, sintiéndose engañada e indefensa ante la Administración. En el origen gitano de las acogidas pretende encontrar la explicación:

JUAN: Porque es lo que estamos hablando de un principio, por eso. (Silencio.) Porque son gitanas. (En voz baja.) Así de claro te lo estoy diciendo (f4).

Nosotros pensamos que la realidad es otra: se trata de la inseguridad de una situación de acogimiento acrecentada por el concepto de familia del colectivo gitano. Al respecto, para evitar una posible recuperación de sus hijas, veamos cómo este padre rompe intencionadamente una larga relación con el patriarca de los gitanos:

JUAN: ¿¿Me entiendes? Este problema lo ha tenido él [patriarca] conmigo, con ninguno más, y nadie se puede meter para ningún problema según las leyes suyas. Y como él y yo seguimos enemistados, cualquier cosa que la gente haga contra mí, él la para (f4).

El único proceso que, por su irregularidad, reportó desde sus inicios vivencias muy negativas en sus vertientes psicológica, jurídica y económica fue el formalizado por unos esposos en Brasil ${ }^{8}$. Esta situación, por otra parte, alerta de los peligros que acechan a los adoptantes que, en solitario, gestionan estas adopciones:

SANTIAGO: No veas cómo te sientes cuando ya el niño lo consideras tuyo y tienes que dejarlo allí. Te sientes impotente en un país en el que te piden dinero y estás con las manos atadas (f5).

Asimismo, pese a que todos los matrimonios reconocen la necesidad y las bondades de estos tiempos de espera, una gran mayoría los percibe excesivamente largos y negativos para la adopción, lo que perjudica a niños y solicitantes:

8. Esta adopción podría catalogarse, como mínimo, de «irregular», pues estos padres encargaron a unos familiares residentes en Brasil apropiarse de un niño. Una madre que no podía hacerse cargo de su bebé (vivía en una favela) fue atendida por estos familiares durante el embarazo y vigilada en el parto. Este control permitió que Mariano pasara de la clínica donde fue alumbrado a la casa de estos familiares. El viaje de estos padres al país para legalizar un proceso colmado de adversidades y corruptelas fue posible, finalmente, gracias a la mediación del consulado español. 
JosÉ: Para que arbitren los recursos, porque un padre que tiene cuarenta y cinco años o una media de cuarenta años no tenga que esperar tres años, de los cuales dos años son para obtener la idoneidad, que te montas en unas medias que en esa edad dos años que corran es mucho. Y los niños tampoco paran de crecer, y eso no es bueno (f7).

También sugieren algunos que, una vez formalizado el acogimiento preadoptivo, la Administración debería agilizar la adopción definitiva. Sobre todo porque las familias biológicas no se rehabilitan y el acogimiento supone un escollo a la hora de satisfacer las necesidades sanitarias, sociales y educativas de los niños.

Respecto al seguimiento, las familias de adopción nacional manifiestan que esta labor ha sido escasa (entre uno y tres contactos) y efectuada siempre durante la fase preadoptiva. Pese a ello, todas dicen que no hay motivos de integración sociofamiliar que los justifiquen, mostrando incluso su satisfacción con la ausencia de los mismos. Así lo indica Pedro: «Sólo una vez. Aunque a nosotros nos ha parecido fenomenal que no nos hicieran más entrevistas, ni seguimiento, ni nada» (f3). Las familias de adopción internacional presentan distintas situaciones. Así, mientras una no había establecido ningún contacto con los técnicos tras la adopción en Brasil, otra que adoptó en Colombia ha tenido uno, y la familia de nuestro estudio con hijos mexicanos habla de dos contactos con la $\mathrm{ECAI}^{9}$. El grado de satisfacción de estos cónyuges se percibe muy elevado. Un padre alerta de su relevancia, pero sigue posicionándose en contra de la Administración, por lo siguiente:

NICOLÁs: Para hacer un buen seguimiento a una familia, primero habría que delimitar en qué principios se basa, qué objetivos son los que se persiguen, qué queremos saber. Es una cosa que se hace y punto. Hombre, el seguimiento debe existir, desde el punto de vista de ayudar, pero ahí no hay nadie capacitado para eso (f6).

\section{Información de la familia adoptiva}

La información que tienen los matrimonios de adopción nacional de los antecedentes y familia biológica de sus hijos, tanto en lo referido a su extensión como a ciertos aspectos concretos, presenta una notable variabilidad. Entre ellas, las familias ( $\mathrm{f} 1 \mathrm{y} \mathrm{f2}$ ), de estatus menos elevado y rurales, son las que tienen un conocimiento más completo. La información de las familias de adopción internacional, a excepción de Santiago y María (f5), que, como sabemos, conocieron de primera mano las circunstancias de su hijo Mariano en Brasil, es bastante más escasa. Este desconocimiento apenas constituye una preocupación para el conjunto de padres y madres. Algunos, incluso, no desean más información:

9. Entidad Colaboradora de Adopción Internacional. 


\section{ENTREVISTADOR: ¿No os dieron más información?}

ANGUSTIAS: Es que la información mínima que tenemos sobre nuestros hijos es suficiente. Yo no quiero más información, no quiero. Es que te marca, te marca. Bueno, si nosotros hubiéramos querido saber más, lo hubiéramos conseguido, pero no hemos querido. Con lo que sabemos, nos basta (f3).

Estas manifestaciones podrían interpretarse como un mecanismo psicológico orientado a evitar la influencia de esta información en las relaciones familiares y esquivar los sentimientos negativos derivados de no transmitir a los hijos, cuando se conoce, este contenido. Las palabras de un padre fluyen en este sentido:

ENTREVISTADOR: ¿Ni se la dieron ni preguntaron?

José: No, si tuviera necesidad de ello, pues sí, pero yo no tengo necesidad de saber si su madre murió o no murió, si era drogadicta... Esto no es importante para la familia. Creemos que sabemos todo lo más relevante (f7).

\section{Información de la condición de adoptado}

Todas las familias de nuestro estudio, sin excepción, han transmitido a sus hijos el significado de la adopción. La mayoría de los matrimonios con niños de menor edad han procedido, desde la acogida y de modo frecuente, a explicarles su estatus con la ayuda de un libro, o bien en forma de cuento, relato o canción (f1, f2, f4, f5). Veamos un ejemplo:

ELVIRA: Yo le digo que era un bebé que no tenía papá ni mamá, aunque nació en la barriguita de otra persona. Entonces viajamos papá y yo hacia una casita en la que había muchos bebés, que no tenían allí a sus papás. Yo, desde que vino, también le cantaba una canción que decía: mi niño tiene tres mamás, la Virgen María, la madre de la barriga y la mamá que lo cuida, que soy yo (f2).

Las familias con niños de más edad, bajo la premisa de que ya conocían su situación o apenas habían mostrado interés, procedieron puntualmente y sin mucha preocupación por estos asuntos (f1, f3, f6, f7). José, dice al respecto: «La mayor ya lo sabe y no hay necesidad de repetírselo» (f7). Prácticamente la mitad de los padres, todos de nivel sociocultural elevado, han hablado con sus hijos por iniciativa propia ( $\mathrm{f} 3, \mathrm{f} 4, \mathrm{f} 5)$ y, el resto, a raíz de las demandas de los hijos (f1, f2, f6, f7). Aunque la mayoría de los matrimonios procedieron de forma conjunta ( $\mathrm{f3}, \mathrm{f} 4, \mathrm{f} 6$ y f7), dos solicitaron, además, la participación de sus hijas mayores (f3 y f6). Sólo en tres familias, dos de residencia rural (f1, f2 y f5), las explicaciones han surgido exclusivamente de la mujer. Así lo expresa Carmela: «Sí, la hago yo. El padre de esto no le habla. Es que no hay un momento para que le hable» (f1). 


\section{Reacciones de los adoptados}

La mayoría de las familias (f1, f3, f4 y f7), salvo dos (f2 y f5), constatan conductas obsesivas y de corte negativo cuando comunican a sus hijos pequeños que no nacieron de sus madres adoptivas ${ }^{10}$. La primera (f2), comenta reacciones entre el negativismo y la rebeldía, y entre la satisfacción y la alegría. La segunda (f5) dice que estas últimas manifestaciones sólo se apreciaron en ocasiones. Las reacciones adversas podrían reflejar un cierto dolor o sufrimiento de los niños por no haber sido concebidos y nacidos de sus madres adoptivas. Las otras, por cuestiones de identificación, revelarían las fantasías despertadas al escuchar ciertos detalles de su trayectoria de vida personal. Sin embargo, entre los que llegaron con mayor edad, se recogen reacciones contrapuestas: de tranquilidad y naturalidad ( $\mathrm{f3}, \mathrm{f} 4, \mathrm{f6})$ o de esquiva de algunos episodios del pasado (f1, f7). Veamos un par de fragmentos:

CARMELA: «¿Y por qué yo no he estado en tu barriguita? Pues yo quiero estar en tu barriguita». Él decía: «Pues no, yo en la tuya» (f1).

ELVIRA: Cuando lo escucha, pone una cara de alegría y dice: «Y yo, ¿qué decía?». Y él mismo empieza como un bebé a decir papá, mamá... Yo creo que al niño le gusta escuchar cosas de adopción. Aunque, a veces, se echa a llorar y dice: «Que no, que yo si estuve en la barriguita de mamál». Entonces, yo le digo: «Bueno, pues ya está, tú dices lo que quieras» (f2).

\section{Información sobre los antecedentes y orígenes}

Pese a la necesidad reconocida que tienen los adoptados de conocer datos de su historia de vida previa y de su familia biológica, ninguna de las familias de nuestro estudio ha recibido un asesoramiento técnico sobre la forma de transmitir esta información. Aunque esta carencia de orientación no impide que los matrimonios reconozcan la inevitabilidad de la misma, sí diversifica las opiniones en torno al mejor procedimiento. Si bien no podemos establecer una diferenciación clara, según los perfiles familiares, una mayoría considera que la revelación de estos contenidos habría de acomodarse a las necesidades de los niños y a la capacidad de comprenderlos (f1, f5, f6, f7). El resto cree que, antes de alcanzar la mayoría de edad, los adoptados no están preparados para asimilar esta información (f2, f3, f4). Una madre se muestra muy preocupada por estas funciones, básicamente por las características de su hijo Gonzalo:

ELVIRA: Además, yo no sé si podré aguantar sus preguntas, porque el niño es muy inteligente. Por eso, cuando tenga unos ocho años y me lo pregunte, yo no sé lo que le voy a decir, porque a esa edad yo no le puedo decir que su madre era gitana y drogadicta. No sé de qué forma lo voy a enfocar luego. No 
es que yo mire que él, el día de mañana, se vaya a juntar con los de su raza, porque yo no soy racista (f2).

Otros padres, cuando sus hijas mayores recuerdan algún acontecimiento de su vida previa, se mantienen al margen sin conceder relevancia a sus comentarios. En ocasiones, posiblemente para neutralizar aquellos factores perturbadores de la estabilidad familiar actual, ofrecen respuestas muy rígidas ante demandas concretas:

PEDRO: Ahora viene la segunda a preguntarme que si yo sé quién fue el médico que la atendió en el parto. Yo le dije: «iLeticia, esa pregunta está fuera de lugar!». Esas preguntas son para ver si tú estás seguro de ser el padre de ellas (f3).

Santiago y María muestran actitudes confusas. Aunque consideran que un buen nivel de confianza familiar se logra sin engañar a los hijos, para ellos lo deseable sería que Mariano no mostrase preocupación por estos asuntos:

SANTIAGO: Claro que el niño irá preguntando y habrá que decírselo (risas de ambos padres). Porque, cuando pida la partida de nacimiento, viene la dirección de la madre. Es que yo no sé por qué la partida de nacimiento, en España, viene así, porque en la brasileña no pone eso para nada. Es que yo he visto en eso una cosa mala, por así decirlo, que si el niño luego no quiere saber, lo mismo que si quiere saber, ¿por qué tiene que verse el nombre de la madre y de dónde viene? (Muestra las partidas de nacimiento española y brasileña) (f5).

\section{Interés por los orígenes: posiciones paternales}

Respecto al interés de los adoptados por reencontrarse con los orígenes, hecho que normalmente ocurre en la mayoría de edad, los discursos, sin excepción, destacan que el móvil para iniciar este camino es la curiosidad. Todas las familias están convencidas de que sus hijos emprenderán esta búsqueda, aunque por razones distintas. Por otra parte, a excepción de un matrimonio (f3), los restantes muestran su disposición para ayudar a sus hijos en este proceso, si bien se observan en las parejas de adopción nacional algunos reparos, temores o condiciones de los que están exentas las de adopción internacional. Veamos el discurso de una madre:

ELVIRA: ¿Por qué él no la va a tener? [la curiosidad] Le ayudaremos por eso hasta dónde haga falta, tanto si es para bueno como para malo, pero siempre y cuando cada uno mantenga las distancias (f2).

Los comentarios de Pedro y Angustias guardan bastante congruencia con el escaso interés mostrado por los antecedentes de sus hijos y por comunicarles su adopción: 
PEDRo: Eso es un problema de ellos, quiero decirte, que mi problema es ser padre y no ser hijo adoptado. Es un problema de ellos, que sabrán cuando tengan dieciocho años qué es lo que quieren hacer. Yo, si tengo ganas de ayudarles, les ayudaré, y, si no, que investiguen solos (se rien ambos padres). Esto es un problema que no lo veo en mí, sino en ellos (f3).

Como anticipamos, las actitudes de los padres de adopción internacional se muestran perceptiblemente diferentes a las de sus homólogos de nacional. El comentario de un padre (f6) puede resultar suficientemente ilustrativo:

NiCOLÁs: Como aquí no se les priva de cualquier conducta relacionada con un interés cultural sobre Colombia. Es que eso es una cosa que habrá que hacer obligada, de ir y decir: «Mira los antecedentes que aquí hay vuestros. Vamos a buscar los datos y..." (f6).

\section{Adaptación familiar y escolar}

Nuestro estudio también ha reflejado cómo los trastornos detectados en los adoptados fueron, en general, bastante frecuentes. Los menos numerosos han sido los de salud: desnutrición (Eva, Leticia y Rebeca), soplo cardiaco (Marisa), y parasitismo (Eva). Estas anomalías, consecuencia de una inadecuada atención en los centros de acogida, desaparecieron con la satisfacción adecuada de estas carencias:

PATRICIA: Se fueron eliminando [los síntomas] rápidamente, al poco tiempo, a base de leche, mucho yogur y mucho apetito que tenían las dos (f6).

Los trastornos de desarrollo han sido más evidentes. Muchos adoptados han tenido problemas relacionados con la aparición y estructuración del lenguaje (Gonzalo), la pronunciación (Gonzalo, Olga y Rebeca) y la fluidez verbal (Rebeca). Asimismo, en el área de la psicomotricidad, Marta e Ignacio presentaron dificultades de coordinación. Sólo una niña, Olga, también reveló dificultades en tareas de distinción de colores y de conceptos básicos. Un padre sostiene:

JUAN: Al principio, la grande [Rebeca] sí los tenía: le costaba mucho hablar seguido y pronunciar. Hablaba como los de Móstoles (f4).

Los trastornos de conducta y/o emocionales, en sus diferentes vertientes, ocupan un lugar destacado. Y no sólo por el número de afectados, sino por su mayor variabilidad y por acumularse en Marta de forma incisiva. De modo que las problemáticas observadas han sido las siguientes: rechazo de normas (Marta, Rebeca y Marisa), enuresis (Marta y Leticia), hiperactividad (Gonzalo e Ignacio), afectividad (Marta, Gonzalo, Ignacio, Leticia y Lorena), celotipia (Marta y Leticia), atención y concentración (Marta y Gonzalo), agresividad (Ignacio), sueño y sexualidad (Marta). A modo de ejemplo, presentamos este testimonio sobre los trastornos de sueño de Marta: 
CARMELA: Pues al principio venía y tenía pesadillas, y se despertaba mucho por las noches. Soñaba en voz alta y decía: «Que entran, que entran!». Se refería a los gatos: «iMamá, los gatos!». Ya se le ha ido, pero no hace tanto (f1).

Como vemos, el caso de Marta, una de las niñas de mayor edad de nuestro estudio, resulta muy relevante. La explicación de su complicada, aunque positiva adaptación familiar, podría encontrarse en la edad de acogida y en sus perniciosos antecedentes: abandono, institucionalización, acogimientos fracasados, malos tratos y abusos sexuales. Frente a este caso, conviene destacar que Mariano, Óscar y Luis, tres de los cuatro niños incorporados a las familias con menor edad, no presentaron ningún problema de salud, ni tampoco de desarrollo o de conducta. Precisamente, en la ausencia de estas adversidades y en la oportunidad de desarrollar un apego temprano y continuado con sus padres adoptivos estaría, en gran medida, la explicación.

También ha sido muy reconfortante comprobar cómo a una gran mayoría de adoptados les va muy bien en la escuela, máxime si reparamos en la historia de estos niños y en sus lagunas escolares. Naturalmente, nuestro análisis se centra en los niños que, por edad, se encontraban en el momento de la entrevista en el sistema educativo. El caso de Marta también ahora resulta evidente: encuentra problemas para superar los estudios y está repitiendo segundo curso de educación secundaria obligatoria. Pese a ello, dice Santiago, que ha experimentado un notable avance, pues «cuando llegó [con siete años] no sabía ni hacer la $\mathrm{O}$ con un canuto» (f1). Sin embargo, según Carmela, la trayectoria de su hija no representa un caso especial, sino una manifestación más de los problemas del sistema educativo: «En su clase hay veinte niños, pues dieciséis van muy parecidos a ella».

Angustias muestra su satisfacción porque sus hijos Olga, Leticia y Óscar «se han integrado muy bien. Han cambiado varias veces de colegio, pero no porque fueran mal, sino por cambios de residencia nuestro, y cada uno está en el curso que le corresponde» (f3). Asimismo, si bien Marisa y Rebeca tuvieron problemas iniciales y les cuesta seguir el ritmo escolar, ahora se encuentran en los niveles educativos adecuados. Estos logros se deben a lo siguiente:

JUAN: En la casa hacemos poesía todos, y ellas también han empezado. Han aprendido a hacerlo porque nosotros las ponemos a escribir. Lo mismo cuando escuchamos música, pues todos la escuchamos. Mis niñas antes no leían y ahora se leen todas las semanas dos o tres libros (f4).

Los resultados alcanzados por los adoptados en el extranjero resultan excepcionales. Así, aunque Eva necesita un constante apoyo educativo, dice Nicolás (f6) que, en cinco años, ha cursado "toda la primaria y cuatro años de secundaria». Añade que, cuando llegó de Colombia, «no sabía prácticamente leer ni escribir. Empezamos con once años con la ma, me, mi, mo, ¿no?». Su hermana Yolanda es una de las más aventajadas de su curso, básicamente porque «no tiene esas carencias propias de la mayor. Ella, claro, vino con tres años y empe- 
zó de nuevo». Otra familia refiere que Lorena y Luis se han adaptado muy bien a la escuela. Al respecto, José destaca: «Sí, yo siempre he dicho que he tenido una gran suerte, por lo menos con mi Lorena, que era la que a mí más me preocupaba, porque Luis, al ser más pequeño, me parecía que iba a tener menos problema con los de su edad» (f7).

Sin asumir demasiados riesgos, pensamos que la razón primordial de estos logros, junto a la relevancia de la edad de acogida y antecedentes, recae en los elevados niveles culturales de la gran mayoría de padres con hijos en edad escolar. Esta formación, la preocupación por el rendimiento escolar de sus hijos y, en consecuencia, la ayuda recibida por los mismos, se perfilan como elementos clave en lo que concierne a la superación de los déficits de aprendizaje iniciales y a la óptima adaptación escolar. Siguiendo la explicación de otros problemas, los perniciosos antecedentes vividos por Marta, la edad de acogida y el bajo nivel sociocultural de sus padres, como acabamos de interpretar, también podrían estar condicionando su irregular trayectoria escolar.

En definitiva, el hecho de que los diferentes trastornos prácticamente hayan desaparecido de la vida de estos niños y niñas, viene a respaldar la eficacia atribuida a este recurso de protección de menores. Además, si tenemos en cuenta la especificidad que revisten las adopciones internacionales y que todas las nacionales (la mayoría de ellas por más de una razón) están catalogadas como «especiales», esta dinámica alcanzaría un mayor grado de expresión.

\section{Satisfacción con la adopción}

Con independencia de las circunstancias y de las peculiaridades recogidas en torno a cada uno de los procesos adoptivos, las familias, sin excepción, manifiestan una gran satisfacción con la adopción y con la vida familiar. Se desprende de los mensajes que, en su conjunto, las parejas destacan ganancias en dinamismo y felicidad familiar, madurez, sensatez, realización personal, unión e interacción, relaciones sociales y altruismo. Veamos uno de tantos fragmentos:

PATRICIA: Como pareja, nos han hecho desarrollar unas capacidades que teníamos nosotros ahí y que, de no tener hijos, las hubiéramos desarrollado de otra forma. Nos ha hecho crecer como personas y llegar a tener una conducta más social (f6).

El hecho de que algunas familias hayan aconsejado y ayudado a otros adoptantes en sus procesos o se hayan planteado una nueva adopción, constituye una prueba adicional del bienestar que venimos destacando. Y es que, al margen del gasto familiar y la dedicación que los niños necesitan, la gran mayoría de familias no expone cambios familiares de importancia. No obstante, en el terreno laboral, la incorporación de los hijos ha hecho a una madre renunciar a la búsqueda de empleo, y a otra abandonar un trabajo que ya venía desempeñando. Carmela (f1) y Elvira (f2) refieren el deseo de sus respectivos esposos en este sentido, bajo el argumento de atender mejor a los hijos. Este 
modo de entender el reparto de roles, como ocurre en estos casos, es bastante común en núcleos familiares de menor estatus socioeconómico y de residencia en ámbito rural:

ELVIRA: Cuando vino el niño, lo consulté con mi marido, pues yo estaba trabajando fija en un supermercado y lo tuve que dejar (f2).

\section{Las actitudes en torno a la adopción}

En este último apartado, hemos pretendido recoger las posiciones de los entrevistados sobre algunos aspectos relacionados con la adopción internacional, adopción "abierta", adopción por parejas homosexuales y, finalmente, sobre el mismo concepto de adopción. En lo que concierne a las razones que llevan a tantas personas a adoptar en otros países, varios testimonios se centran en la carencia de niños exentos de problemas en España y el tiempo tan dilatado que conlleva el proceso de adopción nacional. De igual modo, todos los matrimonios están convencidos de la existencia de tráfico de niños, y aportan alguna información adicional sobre las estrategias utilizadas en los países de origen en torno a esta ilegalidad. Estas adopciones fraudulentas ocurren cuando los adoptantes tratan de agilizar sus procesos para acortar sus estancias y, en consecuencia, el coste económico. Llama la atención que algunos matrimonios aseguren que este tráfico de niños también ocurre en España. Un par de fragmentos permiten visualizar algunas cuestiones:

PEDRO: Esta complejidad hace que los padres intenten agilizar la adopción de la forma que sea, aunque no sea la más legal o conveniente (f3).

NiCOLÁs: Pero se trafica en Colombia y se trafica aquí. Aquí me quisieron vender a mí [unos abogados] una niña cuya madre estaba en la cárcel de Málaga (f6).

Por otra parte, la mayoría de familias muestra un total desacuerdo con la adopción denominada «abierta», que existe en algunos países, o alertan de sus dificultades prácticas: básicamente, porque necesitaría de una gran madurez y coordinación entre padres biológicos y adoptivos y, en consecuencia, provocaría conflictos y repercusiones en el desarrollo psicológico y educativo de los niños (f1, f2, f3, f5 y f7). En todo caso, esta adopción sólo sería aceptada por algunos entrevistados cuando se tratara de hijos desatendidos por razones económicas o por enfermedad de sus padres biológicos:

JUAN: Pero en los otros no. Los otros de violencia, los otros del desagravio total, los otros de los malos tratos, de los malos cuidados o abandonos... (f4).

Pese a que el tema de la adopción por parejas de una misma orientación sexual sólo fue tratado con dos matrimonios ${ }^{11}$, ambos muestran su discon-

11. Cuando se decidió introducir este tema, ya habían sido entrevistadas cinco familias. 
formidad con la autorización legal de la misma. Se observa, sin embargo, que este rechazo obedece a un entendimiento relativamente dispar de la homosexualidad, de modo que Patricia muestra un acuerdo total con los inconvenientes esgrimidos por su marido, básicamente relacionados con el aprendizaje de roles:

NiCOLÁS: De entrada, te diré que me parece un disparate, sinceramente. Es decir, ese niño, por ejemplo, va a ver a dos mujeres, pues hacer vida afectiva, porque mis hijas ven que nosotros nos acostamos juntos y que uno somos hombre y otra mujer, y que ellas, está muy claro, que se van a identificar con el rol de la madre (fo).

Por su parte, Ana, sin mucho convencimiento, considera viable esta opción sólo cuando se trate de niños mayores o con problemáticas especiales. Pero, en coincidencia con su esposo, no está de acuerdo con la adopción homosexual, pues esta conducta contradice lo estipulado por la naturaleza:

José: Yo no la veo. Vamos, por mi formación, yo creo que es antinatural, pues yo creo que la naturaleza ha determinado que los gatos se junten con las gatas, los leones con las leonas y los humanos con las humanas. Yo creo que un niño necesita de un padre y de una madre, porque cada uno tiene sus afectos y sus formas (f7).

Finalmente, en lo relacionado con el concepto y la consideración social de la adopción, se recogen opiniones dispares. Las familias de hábitat rural son las que reproducen la mayoría de comentarios negativos. Estos matrimonios, no obstante, dicen que esta concepción es propia de personas mayores y/o de mentalidad más tradicional, que todavía consideran a la familia adoptiva como un sucedáneo de la biológica, sobre todo por estar muy conectada al concepto de "caridad». Algunas opiniones poco afortunadas se centran, pues, en el valor que en estos ambientes aún se concede a la continuidad genética entre padres e hijos:

ELVIRA: Sí, porque tíos directos de mi marido no han venido a verlo ni siquiera, porque, según ellos, no lo hemos parido y no es, entonces, nuestro (f2).

Por el contrario, prácticamente la totalidad de los comentarios de las familias de ámbito urbano resaltan, además de una adecuada aceptación, una valoración por el hecho de haber adoptado. Las razones que explican estos cambios en los últimos años tienen que ver, según comentan, con el incremento del número de adopciones, con la labor de información a través de la televisión y, en particular, con la publicidad de aquellas adopciones formalizadas por personas de cierta relevancia social:

NiCOLÁs: Ahora yo he notado una evolución muy grande, en los últimos cinco años. He sido consciente de que, quizás, este fenómeno de que a la gente famo- 
sa les haya dado ahora por adoptar haya ayudado muchísimo: Isabel Pantoja, Rocío Jurado... (f6).

\section{Conclusiones}

Los esfuerzos de los matrimonios por superar sus problemas de reproducción alertan de la importancia que sigue teniendo el modelo imperante de familia biológica. De modo que el camino de la adopción sólo es iniciado por los cónyuges ante la obstinada negativa de la naturaleza y, la mayoría, motivados por el deseo de ser padres y formar una familia. Otros, sin embargo, lo hicieron para ayudar a los niños y proporcionar una compañía a la pareja. Pero, en general, quizás como resultado de un proceso de socialización diferenciado, son las mujeres quienes semantizan la mayoría de razones relacionadas con el altruismo. La iniciativa de adoptar surge mayoritariamente de la mujer y, si bien todas las parejas reciben respuestas positivas de familiares y amigos, la etnia gitana de unas acogidas hace que dichas reacciones familiares se produzcan forzadas y sin muestra de agrado.

Respecto a la comparación entre las paternidades biológica y adoptiva se destacan varios aspectos. En efecto, con cierta independencia de los perfiles familiares y desde una perspectiva fenomenológica de los fundamentos, las responsabilidades y las aspiraciones paternales, todos los discursos alertan de una equiparación bastante ajustada entre ambas modalidades. Esta equivalencia se fundamenta en que todas las familias otorgan más influencia en la personalidad y en la conducta de los niños a los factores afectivo-educacionales que a los biológicos. No obstante, frente a determinadas concepciones del entorno, algunos se ven compelidos a defender, si cabe, la paternidad adoptiva sobre la biológica. Básicamente porque la adoptiva no puede resultar de embarazos casuales y ha sido evaluada técnicamente. La necesidad que tienen los niños institucionalizados de encontrar una familia estable es subrayada por todos los matrimonios.

También se observa cómo las familias, sin excepción, desean niños sanos, y todas muestran su indiferencia respecto al sexo. Sin embargo, la mayoría deseaba niños entre tres y seis años, sobre todo por la influencia atribuida a esta variable en el desarrollo de la personalidad, la conducta y la integración familiar. Se ha constatado, en lo que concierne a la etnia gitana de los niños, que esta variable constituye un obstáculo para las familias de nivel más bajo y de hábitat rural. Los cónyuges advierten, no obstante, que estas reticencias surgen de la marginación detectada en estos ambientes, y no de prejuicios personales.

En cuanto a los tiempos de espera y al seguimiento de la familia adoptiva, se observa cierta variabilidad. Aunque la gran mayoría está de acuerdo con estos requisitos, este consenso no impide la existencia de ciertas disconformidades. Así, la mitad de las familias está en desacuerdo con la entrevista como instrumento de selección, por las siguientes razones: gran extensión; inadecuación de contenidos; insuficiente motivación, preparación, experiencia, aser- 
tividad y habilidades sociales de los técnicos; necesidad de experiencia paterna de los profesionales, e introducción de ítems que afectan a la intimidad. Estos inconvenientes son destacados, sobre todo, por los matrimonios de nivel sociocultural más elevado y de residencia en la ciudad. Asimismo, una gran mayoría percibe los tiempos de espera excesivamente largos y negativos para la adopción, fundamentalmente porque las familias biológicas no se rehabilitan, provocan gran ansiedad en los adoptantes y obstaculizan la satisfacción de las necesidades de los niños. El seguimiento de la vida familiar se percibe escaso y algo dispar. No obstante, pese a que los matrimonios reconocen su importancia, la mayoría los considera irrelevantes para la dinámica familiar.

La información que tienen los matrimonios sobre los antecedentes y la familia biológica de sus hijos, tanto en lo referido a su extensión como a ciertos aspectos concretos, presenta una notable variabilidad. En cuanto a la «revelación» de la condición de adoptado, todas las familias, sin excepción, han transmitido a sus hijos esta circunstancia. La mayoría de los matrimonios con niños de menor edad han procedido, desde la acogida y de modo frecuente, a explicarles este estatus ayudándose de un libro, o bien en forma de cuento, relato o canción. Prácticamente la mitad de los padres han hablado a sus hijos por iniciativa propia y, el resto, por circunstancias que podrían situar las demandas en los hijos. Aunque la mayoría procedieron de forma conjunta, en tres familias, dos de ellas de menor nivel sociocultural y rurales, las explicaciones surgieron exclusivamente de la mujer. La mayoría de las familias constatan conductas obsesivas y de corte negativo cuando comunican a sus hijos pequeños que no han nacido de sus madres adoptivas. Sin embargo, en los adoptados de mayor edad, se recogen reacciones contrapuestas: de tranquilidad y naturalidad o, por el contrario, actitudes esquivas y de no querer afrontar la situación.

Por otra parte, pese a la necesidad reconocida que tienen los adoptados de conocer datos de su historia de vida previa y de su familia biológica, ninguna familia ha recibido un asesoramiento técnico sobre la forma de transmitir esta información. Una mayoría, con cierta independencia de los perfiles familiares, considera que la revelación de estos contenidos ha de acomodarse a las necesidades y a las capacidades de los niños. El resto opina que, antes de alcanzar la mayoría de edad, los adoptados no están preparados para asimilar esta información. Respecto a los motivos que podrían llevar a los adoptados a interesarse por sus orígenes, todos los matrimonios se centran en la curiosidad y están convencidos de que sus hijos emprenderán esta búsqueda. Por otra parte, a excepción de unos cónyuges de elevado nivel y hábitat urbano, los restantes están dispuestos a ayudar en este proceso. Pero se observan en los de adopción nacional algunos reparos, temores o condiciones que no existen en los de internacional. Posiblemente, porque éstos últimos interpretan la distancia geográfica como un impedimento para que surjan estos intereses y para que ocurra un encuentro real.

Los trastornos detectados en los adoptados han sido frecuentes. Los menos numerosos fueron los de salud, que sólo afectaron a algunas niñas, siendo algo 
más evidentes los relativos al desarrollo. Por el contrario, los trastornos de conducta y/o emocionales, en sus diferentes vertientes, ocupan un lugar destacado, no sólo por el número de afectados, sino, también, por su mayor variabilidad y por acumularse en una niña (Marta) de forma muy incisiva. Pese a ello, el hecho de que una gran mayoría de los adoptados haya superado o mejorado claramente las distintas problemáticas, constituye la mejor prueba de la eficacia atribuida a este recurso de protección. Sobre todo cuando los acogidos son más pequeños y, en consecuencia, acumulan menos vivencias negativas. $\mathrm{Al}$ respecto, la complicada aunque positiva adaptación de Marta resulta relevante, pues es una de las adoptadas de más edad y de peores antecedentes. Además, si tenemos en cuenta la especificidad que revisten las adopciones internacionales y que todas las nacionales (la mayoría de ellas por más de una razón) están catalogadas como "especiales», los beneficios atribuidos a la adopción alcanzarían un mayor grado de expresión.

También ha sido muy gratificante comprobar cómo a una gran mayoría de adoptados les va muy bien en su centro docente, máxime si reparamos en la historia de estos niños y en sus lagunas escolares. Sin asumir demasiados riesgos, pensamos que la razón primordial de estos logros, junto a la relevancia de la edad de acogida y experiencias previas, recae en los elevados niveles culturales de la mayoría de los padres con hijos escolarizados. Esta formación y la preocupación por el rendimiento de sus hijos han sido elementos clave para superar los déficits de aprendizaje iniciales y adaptarse al sistema educativo. Como recogimos para la explicación de otros problemas, la edad, las circunstancias de Marta y el bajo nivel sociocultural de sus padres podrían estar condicionando su irregular trayectoria escolar. De ahí que todas las familias, con independencia de las particularidades de sus procesos adoptivos, manifiesten una gran satisfacción con la adopción y con la vida familiar. Entre otros enriquecimientos, destacan ganancias en dinamismo y felicidad familiar, madurez, sensatez, realización personal, unión e interacción, relaciones sociales y altruismo.

Los testimonios relativos al auge de la adopción internacional se centran en la carencia de niños exentos de problemas en España y en el tiempo tan dilatado que conlleva una adopción nacional. Por otra parte, la gran mayoría de familias muestra un total desacuerdo con la adopción denominada «abierta», que existe en algunos países, o alerta de las dificultades que conlleva su práctica: básicamente porque necesitaría de una gran madurez y coordinación entre padres biológicos y adoptivos y, en consecuencia, provocaría conflictos y repercusiones en el desarrollo psicológico y educativo de los niños. Asimismo, los dos matrimonios que hablaron sobre la adopción homosexual se mostraron opuestos a la misma, si bien este rechazo obedece a un entendimiento relativamente dispar de las causas que pudieran fundamentar esta orientación sexual. Así, un matrimonio opina que esta conducta es contraria a lo estipulado por la naturaleza y el otro alega inconvenientes relacionados con el aprendizaje de roles.

En torno al concepto y a la consideración social de la adopción, se recogen opiniones dispares. Las familias de hábitat rural son las que reproducen la 
mayoría de comentarios negativos, pues dicen que en estos entornos todavía se considera a la familia adoptiva como un sucedáneo de la biológica y muy conectada al concepto de "caridad». Por el contrario, prácticamente la totalidad de las que viven en un ámbito urbano resaltan una adecuada concepción de la adopción, además de sentirse valoradas por haber adoptado. Las razones que explican estos cambios tienen que ver, según comentan, con el incremento del número de adopciones, con la labor de información a través de la televisión y, en particular, con la publicidad de aquellas adopciones formalizadas por personas de cierta relevancia social.

Finalmente quiero subrayar, como fácilmente puede deducirse de la metodología elegida y del reducido tamaño de la muestra en que he fundamentado este estudio, que mi empeño ha consistido en profundizar en los significados atribuidos por los protagonistas a los distintos elementos de una adopción, y no tanto en una generalización de los resultados. Esta forma de proceder, por otra parte, podría resultar de utilidad para el planteamiento de otros procedimientos encaminados a contrastar el grado de coincidencia entre las dinámicas observadas en estas familias andaluzas y las que podrían derivarse del estudio de un colectivo más amplio.

\section{Referencias bibliográficas}

Alberdi, I. (1995). «Organización formal. Marco legal de la familia». En: Alberdi, I. (dir.), Informe sobre la situación de la familia en España. Madrid: Ministerio de Asuntos Sociales.

AMOrós, P. (1987). La adopción y el acogimiento familiar. Barcelona: Narcea.

Assiego, V. (1998): «Motivaciones para la adopción». Padres y Maestros, núm. 238, p. 26-29.

CASTÓN, P.; OCÓN, J. (2002). «Historia y sociología de la adopción en España». Revista Internacional de Sociología, núm. 33, tercera época, p. 173-209.

CIS (2004). Datos de opinión, número 34 (enero-abril). Madrid.

Convención de las Naciones Unidas sobre los Derechos del Niño, de 20 de noviembre de 1989.

Convenio relativo a la Protección del Niño y a la Cooperación en materia de Adopción Internacional: La Haya, 1993.

Declaración sobre los principios sociales y jurídicos relativos a la protección y bienestar de los niños, con especial referencia a la adopción y colocación en hogares de guarda en los planos nacional e internacional (Resolución 41/85 de la Asamblea General de las Naciones Unidas, de 3 de diciembre de 1986).

Fuertes, J.; Amorós, P. (1996). «Práctica de la adopción». En: Paul Ochotorena, J. de; ARruabarrena, M. I. (coords.). Manual de protección infantil. Barcelona: Masson.

Giberti, E. (1981). La adopción. Padres adoptantes, hijos adoptivos, los otros. Buenos Aires: El Cid.

HERNÁN, J. (1996). «El niño ante la revelación del secreto de la adopción». Infancia y Sociedad, núm. 35, p. 27-34.

Ley 21/1987, de 11 de noviembre, por la que se modifican determinados artículos del Código Civil y de la Ley de Enjuiciamiento Civil en materia de adopción. 
Ley Orgánica 1/1996, de 15 de enero, de protección jurídica del menor, de modificación parcial del Código Civil y de la Ley de Enjuiciamiento Civil.

MarCh, M. X. (1993). La adopción en Mallorca. Una investigación evaluativa. Palma de Mallorca: Universidad de las Islas Baleares. Consejería de Gobernación y Dirección General de Juventud, Menor y Familia.

MeIL, G. (1999). La postmodernización de la familia española. Madrid: Acento.

Morral, M. C. (1987). "La adopción desde una perspectiva psicológica». Menores, núm. 2, p. 39-49.

Ocón, J. (2002). «Reflexiones en torno a la adopción por parejas homosexuales». Cuadernos de Trabajo Social, vol. 15, p. 93-108.

- (2003). Aspectos psicosociales de la adopción en Andalucía (Una aproximación sociohistórica y jurídico-administrativa). Facultad de Ciencias Políticas y Sociología. Departamento de Sociología. Universidad de Granada (tesis doctoral).

- (2005a). «Familia e infancia en la sociedad española». En: Ocón, J. (coord.). Sociología y técnicas de investigación social. Granada: Proyecto Sur de Ediciones.

- (2005b). «Género y sexualidad». En: Ocón, J. (coord.). Sociología y técnicas de investigación social. Granada: Proyecto Sur de Ediciones.

OrellanA, J. (1993). «Algunos problemas derivados de la crianza de niños por personas distintas a los padres, en particular mediante la adopción». Niños, núm. 76, p. 1131.

Palacios y otros (1997). La adopción en Andalucía. Sevilla: Consejería de Asuntos Sociales. Dirección General de Atención al Niño.

RODRIGUES, A. (1997). «A adopçao: um antes; e depois?». Infancia e Juventude, núm. 2, p. 31-70.

RUSKAI, L. (2001). Cómo educar al niño adoptado. Barcelona: Médici.

Secretaría de Estado de Servicios Sociales (2003). Estadística básica de protección a la infancia, núm. 6. Madrid: Dirección General de las Familias y la Infancia. Ministerio de Trabajo y Asuntos Sociales.

VALLES, M. S. (1997). Técnicas cualitativas de investigación social: Reflexión metodológica y práctica profesional. Madrid: Síntesis. 